\title{
Consumption patterns of boarding students
}

\author{
Rahmandhita Aulia Lubiyansyah \\ Department of Anthropology \\ Faculty of Social and Political Sciences, Universitas Airlangga \\ Address: Jalan Dharmawangsa Dalam, Surabaya 60286 \\ E-mail: rahmandhitaaulia@gmail.com
}

\begin{abstract}
Boarding house students are students who migrate. Their consumption patterns are determined by the income they receive each month. The consumption of boarding students, among others, is for food consumption and nonfood consumption. This study aims to analyze the consumption patterns of boarding house students from the class of 2017 in the Department of Anthropology, Airlangga University. The data of this study were obtained from the questionnaire (primary) and interviews with boarding house students from the class of 2017 in the Department of Anthropology, Airlangga University. The results of this study showed that the high-income students tend to be more consumptive compared to the lower income ones.
\end{abstract}

Keywords: boarding house students, students, consumption, migration

\section{Introduction}

Consumption is the activity of shopping for goods or services, the function of which is to meet the needs of those who shop. People shop for their needs with the income they earn. Meanwhile, the portion of income that is not spent is called savings. Every individual needs to meet their needs. Therefore, it cannot be separated from economic activity, one of which is the consumption of goods and services (Julian 2016). Public consumption is divided into two, which are food consumption and non-food consumption (Dumairy 1997). Consumption of food refers to spending income to meet people's needs for food, while non-food consumption is spending income to meet the non-food needs. The expense for food consists of expenditures for grains, tubers, side dishes, prepared foods, prepared drinks, and tobacco or cigarettes. On the other hand, the expenses spent on non-food needs are for housing, fuel, education, health, clothing, durable goods, taxes, premiums, installments, and a variety of other goods and services.

The shift of expenses from food consumption to non-food consumption is the manifestation of the welfare improvement of the society because if thee food needs have been met, then the society will be able to increase their non-food consumption. The consumption pattern of a society depends on the income they receive. In accordance with the differences of income, every individual has different needs and fulfillment of the needs.

A college student is someone who is studying at a university. Students carry out their economic activities every day, just like people who are married. Students also perform consumption activities, i.e. for food and non-food consumption. Non-food consumption for students is related to spending on items needed for university students. Non-food consumption for students is also to meet the needs of transportation, communication for data credit costs, clothing, accessories, and so forth.

Students are not classified as a workforce because students are included in the groups that are not working, looking for a job (unemployed), or currently working (Tama 2014). Students belong to the groups that are in school and do not have permanent income. Students' income usually comes from allowance or scholarships (for those who get scholarships). Allowance from parents is the pocket money received by students every month or every week in accordance with the agreement between parents and the students in question. Although students are not classified as labor force, a lot of them 
have part-time jobs on the sidelines of the lecture time. Their reasons for doing part-time jobs include increasing their allowance, spending their spare time, seeking work experience and so forth.

The allowance earned by students and the income they get from part-time jobs are solely to meet their needs, both the routine and non-routine ones. The expense for routine needs is the spending on the needs of an item that is constantly needed such as food, toiletries, transportation, and so forth, whereas the non-routine needs are the expenditure of unexpected needs, such as buying clothes, traveling, treating friends, and so forth. Such unexpected costs are not predicted in advance, so they are something that has to be noticed (Wurangian et al. 2015).

Currently, the needs of students, especially the ones living in a boarding house, are extremely diverse along with the changing times. Several students sometimes spend their income (allowance) to meet an assortment of non-food needs in order to keep abreast of the current trends. In this case, there is a shift in student's consumption patterns, especially in boarding house students, in terms of how much they spend their income to meet their shopping desires or the things that they should be able to do by themselves to fulfilling their living needs that must be really fulfilled. The family's economic background can also affect their consumption patterns. In general students the background of whom is from rich families will have a high consumption pattern compared to consumption patterns of students with a simple family background.

Some students live in boarding houses and are far from their families. Their consumption patterns are different from the students who live with their parents. Students who live in boarding houses spend more on daily food needs compared to students who live with their parents. This means that needs such as eating and drinking are indemnified by the parents. There are some students who receive scholarships, and for them, income from the scholarships can supplement their allowance. On the vice versa, for students who do not receive scholarships, they only rely on income (allowance) from their parents and income from their part-time jobs (for students who work part-time).

Based on the argument above, it is interesting to study the subjects of this study, who were Airlangga University students, specifically the boarding house students from the Department of Anthropology. Due to various considerations, this study was limited to the class of 2017 students of the Department of Anthropology. Based on this, the issue to study was the way that the boarding house students from the class of 2017 in the Department of Anthropology allocated their income (allowance) that they obtained for consumption activities through a study entitled "Consumption patterns of boarding house students from the class of 2017 in the Department of Anthropology, Airlangga University".

On the basis of the explanation of consumption patterns, especially the consumption of boarding house students and the background that has been previously explained, then the problem that will be discussed in this study are; Does the amount of allowance affect the consumption patterns of boarding house students? How do the boarding house students fulfill the needs other than the basic needs? Finally, how do the boarding students spend their free time and what kinds of economic activities do the boarding house students do?

\section{Method}

The research method in this scientific article employed a quantitative descriptive research method in which there will be a fundamental decryption of the theory that includes the problem to discuss. Then, the researcher measured the quantitative data and objective statistics through scientific calculations based on the samples, boarding house students from the class of 2017 in the Department of Anthropology, who were requested to answer questions about the survey to determine the frequency and percentage of their responses. After that, the conclusion was drawn from the data that had been obtained. 
In addition, this research also used literature study, which refers to gathering some information about research that will be discussed from sources of information such as books, journals, articles and others. Meanwhile, in term of library research, the library is an appropriate place to obtain relevant materials and information to be collected, read and studied, recorded and utilized (Roth 1986 in http://phairha.blogspot.com/2012/01/studi-kepustakaan.html).

\section{The Research Result and Discussion}

The relationship between the society and development mobility can influence development progress. There is development in education, as an instance. This development also has an impact on migration activities because migration will open aspirations to the population. According to Munir (2010) in Zubaidah et al. (2015), migration is frequently interpreted as a relatively permanent migration from one area to another. There are two types of population mobility that are generally related to work or education:

1. Circular migration or seasonal migration, i.e. migration where a person moves, but he is not settled there and still has a family in or is related to his area of origin.

2. Commuter migration, which refers to a person who leaves his residence every day and goes to another city to study, work or trade and so on, but returns home in the afternoon.

Every year students always experience migration. The destination areas of the migration of the students are big cities that are considered good both in the development and education. There are so many driving factors that make students interested in coming to study in big cities, one of which is Surabaya. The reasons that they migrate to Surabaya are the availability of educational facilities (primary, secondary, and higher education), the hospitality of people in the migration destinations, affordable and inexpensive cost of living. It occurs to be the same for the class of 2017 students of the Department of Anthropology since most of them are students from out of town.

At this time, cities that are equipped with adequate educational facilities is an attraction for students in Indonesia who have an interest in education. The factors influencing students to migrate for education are the quality of education, university location, future career development, and so on (Semiv \& Semiv 2010).

Migrant students who come to Surabaya to study mostly live in boarding houses (boarding house students). Boarding house or lodging house is a service that offers a room or place to live with a certain amount of payments for every specified period. The payment is generally per month (https://id.wikipedia.org/wiki/Indekos). As boarding house students, they also have consumption patterns or consumption activities like those carried out by households in general. Consumption itself means an activity that aims to reduce or consume the usefulness of an object, both in the form of goods and services, to meet the needs and satisfaction directly (http://id.wikipedia.org/wiki/Konsumsi).

Quoting the consumption theory with relative income hypothesis in Darmadi (2017?), James Duesenberry suggests the theory of consumption with the relative income hypothesis utilizing two assumptions, which are:

1.A household's taste in consumer goods is interdependent. Interdependent is the expenditure of household consumption that is influenced by the expense of the surrounding people (the neighbors).

2.Consumption expenditure is irreversible. Irreversible refers to the differences between the expense patterns of a person when his income rises and the pattern of expenses when his income decreases.

The amount of allowance for every boarding house student is not the same, but the environment where he lives often affects the consumption patterns that he does. Therefore, boarding house students are required to be able to choose consumption patterns that are in accordance with the amount of allowance 
that they receive in order to meet the needs and available supplies. The amount of allowance received by the boarding house student also influences the consumption patterns that he does. Students who receive higher income (allowance) will consume more compared to students who receive lower income (Wurangian et al. 2015).

Teenagers are at a transitional stage and in the process of finding their identity. Teenagers seek and try to achieve the ideal self-pattern. This makes teenagers easily influenced by the promotion of goods or services in the market. As an instance, markets are releasing more and more products the target of which is teenagers. This proves that teenagers' consumption is very high (Gumulya and Widiastuti 2013). The consumption patterns of students who tend to always want all the conveniences and practicality make their consumption patterns tend to be high and can be regarded as consumptive students. Such a pattern depends on factors that make them consumptive in managing the income (allowance) that they get. Public order, according to Baudrillard (1998) in Ulfa (2012), explained that the rationality of hedonism has been resting on satisfying needs and pleasure through consumption. When observed, the traditional life that is filled with the doctrine of piety, modesty, and the properties of altruistic and the restraint of desire or lust has been shifted a lot. Thus, life rests more on hedonistic moral that puts improvidence that is spread by mass media forward (Baudrillard 1998).

The expense patterns of students are the spending value carried out by students to meet all their needs. Broadly speaking, the needs of students are grouped into two broad categories that are food and nonfood needs. Consequently, at a certain level of income, students will allocate their income to meet both needs (Wurangian et al. 2015). The questionnaire below was filled by several boarding house students from the class of 2017 in the Department of Anthropology at Airlangga University on December 4, 2017

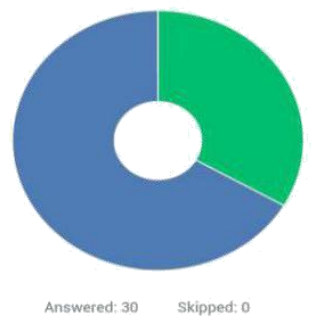

Figure 1

Frequency of respondents' gender

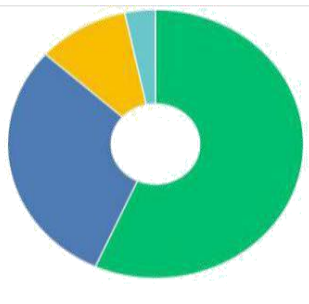

Figure 2

\begin{tabular}{|lll}
$\mid$ Male & $33.33 \%$ & 10 \\
\hline Female & $66.67 \%$ & 20
\end{tabular}

\begin{tabular}{lll} 
Under Rp1.000.000 & $56.67 \%$ & 17 \\
\hline Rp1.000.000- & & \\
Rp1.500.000 & $30 \%$ & 9 \\
\hline Rp1.500.000- & & \\
Rp2.000.000 & & 3 \\
\hline
\end{tabular}

Frequency of income (allowance) every month 


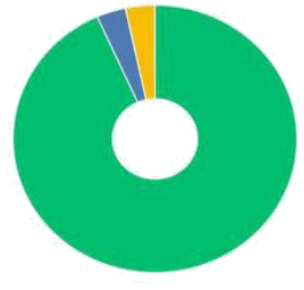

Figure 3

Frequency of expenses of basic needs for a day

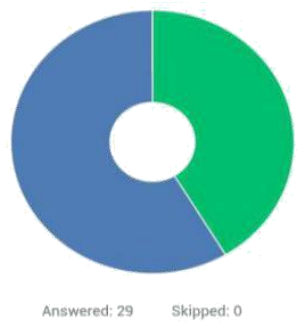

Figure 4

Frequency of using laundry services

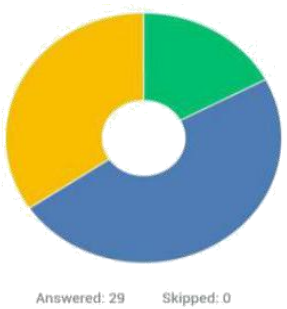

Staying at the boarding house $48.28 \%$

Walking around

$34.48 \% \quad 70$

Figure 5

Frequency of entertaining activities from the respondents' college activities

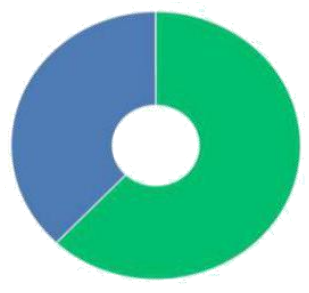

\begin{tabular}{|lrr}
\hline Enough & $6207 \%$ & 18 \\
\hline Not enough & $37.93 \%$ & 11 \\
\hline
\end{tabular}

Figure 6

Frequency of income (allowance) adequacy to the monthly needs of the respondents

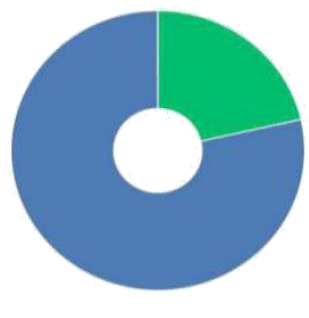

\begin{tabular}{|lll}
\hline There is & $21.43 \%$ & 6 \\
\hline Nothing & $78.5 \% \%$ & 22 \\
\hline
\end{tabular}

Figure 7

Frequency of respondents with part-time jobs and without part-time jobs 
Based on the questionnaire data, the participants in the questionnaire were dominated by female boarding house students. The statistical data shows $33.33 \%$ for male participants and $66.67 \%$ for female participants. Based on Figure 2, it could be identified that the average of income (allowance) per month obtained by the boarding house students was below Rp500.000,00 with the percentage of $56.67 \%$. Meanwhile, for the remaining respondents, $30 \%$ of them received the income (allowance) between Rp1.000.000,00 to Rp1.500.000,00, 10\% got the income (allowance) between Rp1.500.000,00 to Rp2.000.000,00, and finally, 3.33\% obtained the income (allowance) above Rp2.000.000,00. The majority of boarding house students spent the consumption expenditure of Rp50.000,00 per day (the percentage of $93.33 \%$ ). There were some who spent money above Rp50.000,00 to meet their daily consumption costs.

In Figure 4, the question is whether boarding house students use laundry services instead of washing their own clothes. The results from the percentage are not far adrift. The answer "Yes" came from as many as $41.38 \%$ of the respondents and the answer "No" resulted from $58.62 \%$ of respondents. This shows that quite a lot of students used laundry services even though they were still dominated by students who washed their own clothes to save on their living expenses.

The fifth question in Figure 5 asks what the boarding house students do when they have leisure time associated with consumption and cost savings in living. $48.28 \%$ of students answered "staying at the boarding house" which means that to spend their free time, students would only stay at the boarding house and did their activities there such as doing assignments, watching movies, and enjoying other entertainment that did not require spending a lot of money, whereas $17.24 \%$ of students did their activities in the library, and the remaining $34.48 \%$ chose to go traveling or shopping to enjoy themselves when they had some free time.

Figure 6 answers the question about whether or not the boarding house students receive sufficient amount of income (allowance) to meet their needs during becoming student migrants. The answer was "sufficient" with the percentage of $62.07 \%$. while the remaining $37.93 \%$ answered "insufficient".

Figure 7 shows that some students felt that their income was insufficient to meet their daily needs. They said that they had a part-time job that they had to do during their study in college. Their reasons for choosing to do part-time jobs among which were to increase the allowance, to help their parents, and to get some work experience. Some of the examples of the student's part-time jobs were trading online, selling cellphone credit, painting, and so forth. The percentage for the answer "Yes" was $21.43 \%$, and the rest answered "No", which means that they did not do/have part-time jobs, with the respondents' answers of $78.57 \%$.

Based on these results, it can be concluded that studying in university has a major influence on the consumption patterns of the students, especially for the boarding house students. Their condition is totally different from students who live with their parents who are already guaranteed in terms of primary consumption such as food, drink, transportation, education and so on. The need of food is the number one priority need of boarding house students in meeting their daily needs. The income earned by boarding house students also affects the patterns or ways to entertain themselves in their spare time outside the lecture hours. As an instance, students with high income (allowance) will tend to choose to go traveling compared to students who earn less income (allowance) who prefer to spend their leisure time at the boarding house only or visit the library. The desire of students to get a life in their migration city with perfect patterns can also be realized by working part-time to meet their consumption needs.

\section{Conclusion}

Based on the results of research and discussion above, it can be concluded that the consumption patterns of students depend on the size of the income they get. If students who have small income, then they tend to put up with it and fulfill their needs according to the income they earn, but they do not rule 
out the possibility of having part-time jobs with the aim of increasing their income in addition to the income given by their parents. Non-food consumption patterns include traveling that is carried out by students who have high incomes. Students who have low income tend to stay only in a boarding house or visit the library. The suggestion that researchers propose in this article is that students should be more precise in spending their income (allowance). Specifically, in order to meet their primary needs as boarding house students, they should be able to learn independently by doing things that are possible to do by themselves without having to spend extra expenses, such as cooking by themselves, washing their own clothes and so forth. Furthermore, it would be wiser to manage their finance as a boarding house student.

\section{References}

Baudrillard J (1998) The consumer Society: Myth and Structures. London: Sage Publication.

Darmadi V (2017?) Teori Konsumsi 1 Faktor Ekonomi. [Diakses 1 Desember 2017]. https://docplayer.info/30457338-Teori-konsumsi-1-faktor-ekonomi.html

Dumairy (1997) Perekonomian Indonesia. Yogyakarta: Erlangga.

Gumulya J \& Widiastuti M (2013) Pengaruh konsep diri terhadap perilaku konsumtif mahasiswa Universitas Esa Unggul. Jurnal Psikologi 11 (1): 50-65.

Julian (2016) Pola konsumsi mahasiswa indekos di Universitas Lampung (Studi kasus: Mahasiswa S1 Reguler UNILA). Skripsi, Universitas Lampung, Lampung.

Semiv L \& Semiv R (2010) Regional peculiarities of educational migration in Ukraine. Economics \& Sociology 3 (1): 123-132. doi: 10.14254/2071-789X.2010/3-1/12.

Tama RT (2014) Pengeluaran Konsumsi Mahasiswa Program Studi Pendidikan Ekonomi Fakultas Ekonomi Universitas Negeri Yogyakarta. Skripsi, Universitas Negeri Yogyakarta, Yogyakarta.

Ulfa NS (2012) Konsumsi Sebagai Penanda Kesejahteraan Dan Stratifikasi Sosial (Dalam Bingkai Pemikiran Jean Baudrillard). Forum 40 (2): 34-41.

Welcome in Airha's Blog (2012) [Diakses 1 Desember 2017]. http://phairha.blogspot.com/2012/01/studi-kepustakaan.html.

Wikipedia (2017) Indekos. [Accessed 1st December 2017]. https://id.wikipedia.org/wiki/Indekos.

Wikipedia (2017) Konsumsi. [Accessed 1st December 2017]. http://id.wikipedia.org/wiki/Konsumsi.

Wurangian F, Engka D, \& Sumual J (2015) Analisis Pola Konsumsi Mahasiswa Fakultas Ekonomi \& Bisnis Universitas Sam Ratulangi Yang Kost di Kota Manado. Jurnal Berkala Ilmiah Efisiensi 15 (2): 74-87

Zubaidah E, Hamidah S, Mustadi A, \& Pratiwi PH (2016) Migrasi Pelajar dan Mahasiswa Pendatang di Kota Pendidikan. In: Prosiding Seminar Nasional Meneguhkan Peran Penelitian dan Pengabdian kepada Masyarakat dalam Memuliakan Martabat Manusia, 26-27 April 2016, Yogyakarta. Yogyakarta: LPPM Universitas Negeri Yogyakarta, 597-608. 